\title{
Analisis Manajemen Event di Kriyad Hotel Bumiminang Padang Ditinjau dari Fungsi Pengawasan
}

\author{
Lise Asnur $^{1 *}$, Yuliana², Sukma Yudistira ${ }^{3}$ \\ 123,Program Studi D4 Manajemen, Jurusan Pariwisata FPP Universitas Negeri Padang
}

\section{A R T I C L E I N F O}

Article history:

Received 01 December 2019

Received in revised form

31 December 2019

Accepted 15 January 2020

Available online 26

February 2020

\section{Kata Kunci:}

Manajemen, Event,

Pengawasan, Hotel

Keywords:

Management, Event,

Controlling, Hotel.

\begin{abstract}
A B S T R A K
Penelitian ini bertujuan untuk mengetahui Analisis Manajemen Event di Kyriad Hotel Bumiminang Padang ditinjau dari fungsi pengawasan. Penelitian ini terdiri dari indikator fungsi manajemen yaitu pengawasan. Penelitian ini merupakan penelitian deksriptif dengan pendekatan data kuantitatif dan kualitatif metode mixed. Populasi pada penelitian ini sebanyak 653 orang. Teknik pengambilan sampel mengunakan Proporsional Random Sampling, dengan jumlah sampel sebanyak 87 orang. Data dikumpulkan melalui wawancara dan menyebarkan kuesioner (angket) dengan mengunakan skala Likert yang telah teruji validitas dan reliabilitasnya. Hasil penelitian menunjukkan bahwa manajemen event di Kyriad Hotel Bumiminang masih memiliki beberapa kendala dan kekurangan ditinjau fungsi pengawasannya. Berdasarkan data analisis dengan IBM SPSS versi 25, menunjukkan bahwa manajemen event di Kyriad Hotel Bumiminang ditinjau dari indikator pengawasan termasuk kategori cukup baik dengan persentase $44 \%$.
\end{abstract}

\section{A B S T R A C T}

This research aims to determine the analysis of event management in Kyriad Hotel Bumiminang Padang in terms of controlling. This research is consist of controlling as indicator. The type of this research is descriptive research with quantitative and qualitiative data approaches with mixed method. The population in this research is 653 people. The sampling technique is using proportional random sampling with total sample is 87 people. Data is collected through interview and distributing questionnaires using likert scale that has been tested for validity and reliability. The results showed that event management in Kyriad Hotel Bumiminang Padang still had several obstacles and shortcomings in terms of controlling. Based on data analysis with IBM SPSS version 25, shows that event management in Kyriad Hotel Bumiminang in terms of controlling indicator category is quite good with percentage $44 \%$.

\footnotetext{
* Corresponding author.

E-mail addresses: lise.asnur@fpp.unp.ac.id (Lise Asnur)
} 


\section{Pendahuluan}

Di era saat ini industri pariwisata di Indonesia tumbuh maju dan menjadi sebagai salah satu pertumbuhan perekonomian. Pariwisata tetap menjadi salah satu kegiatan ekonomi nasional paling signifikan yang menunjukkan pertumbuhan substansial dalam dekade-dekade sebelumnya dan dapat dilihat sebagai instrumen utama untuk pembangunan daerah karena merangsang berbagai kegiatan dengan dampak ekonomi positif pada neraca pembayaran, Produk Domestik Bruto (PDB) , pekerjaan dll. Tujuan wisata tergantung pada pengunjung reguler dan sering (Darnell \& Johnson, 2001). Faktor-faktor penentu dari kunjungan berulang memiliki makna khusus bagi para pemangku kepentingan industri pariwisata karena "dengan memahami hubungan antara perilaku masa depan dan faktor-faktor penentu, para manajer pariwisata tujuan akan lebih tahu tentang bagaimana membangun citra yang menarik dan meningkatkan upaya pemasaran mereka untuk memaksimalkan penggunaan sumber daya "(Chen \& Tasi, 2007).

Pariwisata modern terkait erat dengan pengembangan dan mencakup semakin banyak tujuan baru. Menurut Organisasi Pariwisata Dunia (UNWTO, 2016), semakin banyak tujuan di seluruh dunia telah dibuka untuk, dan berinvestasi dalam pariwisata, mengubahnya menjadi pendorong utama kemajuan sosial ekonomi melalui penciptaan lapangan kerja dan perusahaan, pendapatan ekspor , dan pengembangan infrastruktur. Selama beberapa dekade terakhir, kuantitas, variasi, dan daya tarik acara telah meningkat, dan pasar menjadi lebih kompetitif. Peristiwa baru harus sangat inovatif dan orisinal agar dapat bersaing dalam hal menarik artis, pelayan, dan dukungan keuangan (Getz 1997). Diperlukan fasilitas untuk destinasi agar kompetitif dalam menyelenggarakan acara, dan acara dapat merangsang pembangunan fasilitas baru.

Perkembangan pariwisata Indonesia yang cukup pesat dapat terlihat dari jumlah kunjungan wisatawan mancanegara ke Indonesia yang meningkat. Dapat dilihat pada perkembangan jumlah kunjungan wisaman sebagai berikut:
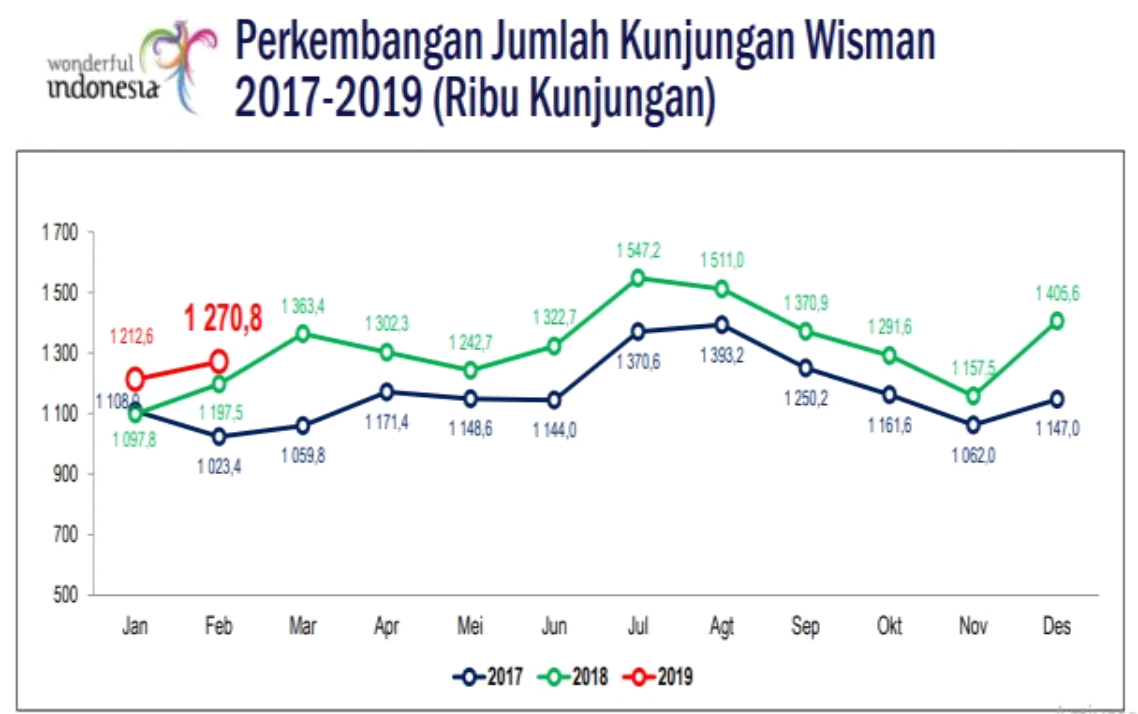

Gambar 1. Grafik Perkembangan Jumlah Kunjungan Wisman

Berdasarkan gambar tersebut relihat adanya peningkatan dari tahun 2017-2019. Selain produkproduk tujuan wisata, citra destinasi wisata juga berperan dalam mempengaruhi keputusan wisatawan berkunjung.

Event tourism adalah dunia beragam acara yang direncanakan dengan berbagai ukuran dan cakupan untuk budaya, olahraga, politik, dan bisnis, dan lainnya. Sebagai tempat wisata, acara berbeda dari yang dibangun dan permanen karena keunikannya dalam waktu dan tempat, serta berbagai pengalaman yang dapat mereka tawarkan. Karena pariwisata adalah bidang bisnis yang berkembang pesat, terjadi peningkatan persaingan antara destinasi, wilayah, dan masyarakat. Oleh karena itu telah menjadi fitur penting dari strategi pemasaran di antara tujuan, karena acara dapat bermanfaat dalam fungsi ekonomi, lingkungan dan sosial masyarakat. Event adalah kontributor penting bagi kesejahteraan masyarakat (Getz, 1997).

Event merupakan kegiatan yang diselenggarakan untuk memperingati hal-hal penting baik secara individu maupun kelompok, kegiatan diselenggarakan untuk tujuan tertentu serta melibatkan lingkungan 
masyarakat. Salah satu tujuan sebuah event diselenggarakan adalah terdapat pada sasaran dan target pengunjung (Noor, 2013). Unit untuk event pariwisata semakin banyak didirikan dalam organisasi pariwisata. Ketika fenomena telah berkembang menjadi kemungkinan untuk membuat bisnis, banyak peluang untuk profesionalisme muncul dan perusahaan-perusahaan penyelenggara acara bermunculan di mana-mana. Akibatnya, event pariwisata semakin diakui di beberapa tempat.

Terdapat empat kriteria manajemen menurut Terry dalam Wijaya dan Rifa'i (2016) yang harus dipenuhi untuk mencapai keberhasilan sebuah event, yaitu planning (perencanaan), organizing (pengorganisasian), actuating (pelaksanaan) dan controlling (pengawasan).

Kyriad Hotel Bumiminang Padang merupakan hotel berbintang empat di Kota Padang yang memiliki arsitektur megah dengan bentuk bangunan modern namun tanpa meninggalkan nilai-nilai tradisional khas Sumatera Barat.Hotel ini memiliki total 164 kamar dan 9 function room yang menjadi penunjang kegiatan operasional hotel.

Tabel 1. Kapasitas Function Room Kyriad Hotel Bumiminang Padang

\begin{tabular}{lllllll}
\hline \multirow{2}{*}{ NAME } & \multicolumn{2}{l}{$\begin{array}{l}\text { CAPACITY / pax } \\
\text { U-Shape }\end{array}$} & $\begin{array}{l}\text { Round } \\
\text { Table }\end{array}$ & \multicolumn{2}{l}{ Class Room Board Room Theatre } & Standing \\
\hline Puti Bungsu & 175 & 700 & 600 & 100 & 1200 & 1500 \\
Gumarang & 50 & 80 & 70 & 50 & 100 & 130 \\
Binuang & 25 & 50 & 40 & 25 & 50 & 70 \\
Kinantan & 25 & 50 & 40 & 25 & 50 & 70 \\
Arau & 25 & 50 & 40 & 25 & 50 & 70 \\
Anai & 25 & 50 & 40 & 25 & 50 & 70 \\
Pagaruyuang & 50 & 80 & 70 & 50 & 100 & 130 \\
Sianok & 10 & 10 & 10 & 10 & 20 & 30 \\
Mentawai & 25 & 40 & 30 & 30 & 60 & 80 \\
\hline
\end{tabular}

Sumber: Dokumentasi Departemen Sales \& Marketing

Berdasarkan sumber pra penelitian pada Bulan April 2019, terlihat segi controlling (pengawasan), terdapat permasalahan seperti banyaknya event di hotel membuat staf sales and marketing tidak bisa mengawasi semua event yang berlangsung sehingga tidak dapat memastikan kepuasan tamu ketika event berlangsung. Kemudian daripada itu, pihak hotel belum ada menyediakan semacam feedback form untuk menilai bagaimana kepuasan klien setelah melaksanakan event di Kyriad Bumiminang, sehingga komplain dan masukan dari klien tidak dapat di teruskan kepada departemen yang bersangkutan dan tidak dapat ditindaklanjuti untuk kemajuan penyelenggaraan event selanjutnya.

Manajemen yang baik akan menuntun kepada keberhasilan sebuah event, maka penulis berkeinginan untuk melakukan penelitian mengenai manajemen event di Kyriad Hotel Bumiminang Padang dengan judul "Analisis Manajemen Event di Kyriad Hotel Bumiminang Padang ditinjau dari Fungsi Pengawasan". Pentingnya penelitian ini dilakukan adalah untuk memperbaiki kekurangan-kekurangan dalam manajemen pelaksanaan event sehingga dapat menghasilkan event yang melebihi ekspetasi yang diharapkan klien dan memberikan kesan positif terhadap citra hotel. Penelitian ini diharapkan dapat memperoleh informasi mengenai penyebab permasalahan yang terjadi seputar pelaksanaan event pada saat ini di Kyriad Hotel Bumiminang Padang dan menemukan solusinya yang dipaparkan secara ilmiah.

\section{Metode}

Jenis penelitian ini adalah penelitian deskriptif dengan pedekatan data kualitatif dan kuantitatif dengan metode mixed. Populasi penelitian ini berjumlah 653 orang dengan jumlah sampel 87 orang. Teknik pengambilan sampel yang digunakan pada penelitian ini yaitu probability sampling dengan teknik simple random sampling. Penelitian ini menggunakan data primer dan data sekunder, diperoleh dari observasi, dokumentasi, wawancara dan menyebarkan kuesioner yang terdiri dari 20 pernyataan yang telah diuji validitas dan reliabilitasnya. Selanjutnya data akan diolah menggunakan IBM SPSS versi 25. 


\section{Hasil dan pembahasan}

\section{Pendekatan Kualitatif}

Karyawan maupun pihak manajemen selalu berusaha untuk memberikan solusi terhadap kesalahan-kesalahan yang terjadi, namun tindakan koreksi jarang dilakukan padahal dengan dilakukannya tindakan koreksi dapat mencegah terjadi kesalahan yang sama sehingga komplain tamu berkurang. Kemudian, meskipun belum ada standar yang jelas dan tertulis, karyawan selalu berusaha untuk melakukan perkerjaan sesuai dengan standar yang dilakukan secara turun-temurun dari senior sebelumnya, namun karena belum jelasnya standar yang ada membuat butuh waktu bagi karyawan yang baru untuk beradaptasi dan mengingat urutan kerjanya. Diharapkan juga kepada pihak manajemen untuk aktif dan turun kelapangan untuk melihat secara langsung bagaimana operational hotel berjalan salah satunya yaitu penyelenggaraan event di hotel sehingga dapat secara langsung menilai dimana kekurangan selama penyelenggaraan event dan hal-hal apa saja yang bisa ditingkatkan untuk menjadi nilai plus penyelenggaraan event di Kyriad Hotel Bumiminang Padang di mata para konsumen.

\section{Pendekatan Kuantitatif}

Data diperoleh dari hasil kuesioner yang telah diisi oleh sebanyak 87 orang panitia pelaksana acara yang telah diuji validitas dan reliabilitasnya. Bersumber dari pengisian kuesioner maka dapat diperoleh deskripsi data seperti yang terlihat pada Tabel berikut:

Tabel 2. Deskripsi Data

\begin{tabular}{|c|c|c|c|}
\hline \multirow{2}{*}{$\begin{array}{l}\text { Kategori } \\
\text { Sangat Baik }\end{array}$} & Rentang Skor & $\mathbf{F}$ & \multirow{2}{*}{$\begin{array}{c}\% \\
0\end{array}$} \\
\hline & $>16,05$ & 0 & \\
\hline Baik & $13,35-<16.05$ & 3 & 3 \\
\hline Cukup Baik & $10,65-<13,35$ & 38 & 44 \\
\hline Kurang Baik & $7,95-<10,65$ & 32 & 37 \\
\hline Tidak Baik & $<7,95$ & 14 & 16 \\
\hline \multicolumn{2}{|c|}{ Total } & 87 & 100 \\
\hline
\end{tabular}

Berdasarkan Tabel di atas dapat dijelaskan bahwa dari 87 tamu untuk variabel manajemen event di Kyriad Hotel Bumiminang Padang ditinjau dari indikator pengawasan dapat dikelompokkan sebagai berikut: sebanyak $0 \%$ responden menunjukkan kategori sangat baik, 3\% responden menunjukkan kategori baik, 44\% responden menunjukkan kategori cukup baik, 37\% responden menunjukkan kategori kurang baik dan $16 \%$ responden menunjukkan kategori tidak baik.

Fungsi pengawasan dalam manajemen meliputi pengukuran hasil dari yang telah direncanakan, mengawasi hasil dari manajemen yang telah dilakukan dan melakukan tindakan koreksi terhadap penyimpangan-penyimpangan yang terjadi selama kegiatan manajemen. Berdasarkan hasil observasi dan wawancara yang peneliti lakukan terkait fungsi pengawasan pada manajemen event di Kyriad Hotel Bumiminang Padang, ditemukan beberapa kekurangan seperti tidak adanya semacam feedback form yang diisi oleh tamu setelah tamu menyelenggarakan event di Kyriad Hotel Bumiminang Padang, feedback form ini berfungsi sebagai tolak ukur untuk menilai bagaimana penyelenggaraan event di Kyriad Hotel Bumiminang Padang dan seberapa puas tamu terhadap penyelenggaraan event di Kyriad Hotel Bumiminang Padang, karena pada feedback form ini berisi keluhan, kritik, saran dan penilaian oleh tamu. Dengan adanya feedback form, maka pihak hotel dan manajemen hotel dapat melihat kelebihan dan kekurangan dari penyelenggaraan event di Kyriad Hotel Bumiminang Padang, untuk dapat mempertahankan kelebihannya dan memperbaiki kekurangan-kekurangan yang terjadi selama penyelenggaraan event. Kekurangan selanjutnya yaitu tidak adanya tindakan koreksi oleh pihak manajemen hotel terhadap kekurangan dan penyimpangan yang terjadi selama pelaksanaan event sehingga kesalahan yang sama terus terjadi dan komplain yang sama tetap bermunculan.

Hal ini dapat berubah menjadi baik dan sangat baik apabila pihak manajemen melakukan usahausaha untuk selalu mengawasi hasil dari penyelenggaraan event yang telah dilaksanakan dan konsisten untuk melakukan tindakan koreksi terhadap kekurangan dan penyimpangan yang terjadi selama kegiatan manajemen event . 


\section{Simpulan dan saran}

Indikator pengawasan dalam manajemen event di Kyriad Hotel Bumiminang Padang sudah cukup baik karena event-event yang diselenggarakan dapat berjalan dan tujuan dari event tercapai. Meskipun ditengah- tengah penyelenggaraan event masih terdapat beberapa kekurangan yang menimbulkan komplain tamu. Kemudian hotel masih belum menyediakan feedback form sebagai alat ukur kepuasan tamu yang menyelenggarkan event di Kyriad Hotel Bumiminang Padang dan untuk menampung keluhan, kritik dan saran tamu yang nantinya berguna sebagai acuan dalam melakukan evaluasi dan perbaikan untuk masa selamjutnya. Dilihat dari hasil evaluasi berdasarkan kuesioner yang telah diisi responden, sebanyak $44 \%$ responden menyatakan cukup baik.

Adapun saran yang dapat disampaikan penulis dalam penelitian ini adalah:

Diharapkan kepada pihak manajemen hotel untuk selalu memastikan bahwa kegiatan manajemen event di Kyriad Hotel Bumiminang Padang berjalan dengan semestinya dan memantau apakah tujuan dari manajemen event telah tercapai atau belum.

Agar dapat mengetahui tingkat kepuasan tamu terhadap penyelenggaraan event di Kyriad Hotel Bumiminang Padang, sebaiknya pihak manajemen hotel menyediakan semacam feedback form yang dapat menampung keluhan, kritik dan saran dari tamu. Dari feedback form ini nantinya dapat diambil kesimpulan hal apa saja yang harus dipertahankan dan apa saja yang harus diperbaiki berkaitan dengan manajemen event guna mendatangkan citra positif dalam hal penyelenggaraan event di Kyriad Hotel Bumiminang Padang.

\section{Daftar Rujukan}

Abdullah, Iqbal Alan. 2009. Manajemen Konferensi dan Event. Yogyakarta: Gajah Mada University Press.

Andriansyah, Rifki. 2017. "Analisis Pelaksanaan Fungsi-Fungsi Manajemen untuk Meningkatkan Aksesibilitas Penyandang Disabilitas pada Pilkada Serentak 2015". Skripsi Bandara Lampung: Fakultas Ilmu Sosial dan Ilmu Politik Universitas Lampung.

Arikunto, S. 2013. Prosedur Penelitian: Suatu Pendekatan Praktik. Jakarta: Rineka Cipta.

Chen, C. F., \& Tsai, D. (2007). How destination image and evaluative factors affect behavioral intentions? Tourism Management, 28, 1115- 1122.

Darnell, A. C., \& Johnson, P. S. (2001). Repeat visits to attractions: a preliminary economic analysis. Tourism Management, 22, 119-126.

GETZ DONAL. 1997. Event Management \& Event Tourism. New York. Cognizant Communication Corporation. ISBN 978-1882345465

Handoko, T Hani. 2012. Manajemen Edisi 2. Yogyakarta: BPFE.

Ismayanti. (2010). PENGANTAR PARIWISATA. Jakarta : Grasindo.

Noor, Any. 2013. Manajemen Event. Bandung: Alfabeta.

Pemerintah Indonesia. 1990. UU No. 9 Tahun 1990 tentang Kepariwisataan. Departemen Pariwisata, Jakarta: Sekretariat Negara.

Pudjiastuti, W. 2010.Special Event Alternatif Jitu Membidik Pasar.Jakarta: PT Alex Komputindo.

Pudjiastuti, Wahyuni. 2013. Manajemen Special Event.Jakarta: Kementrian Pendidikan dan Kebudayaan.

Rosyida, Satwika. 2016. “ Analisis Manajemen Event Gumelem Ethnic Carnival Tahun 2016 dalam Melestarikan Kebudayaan di Gumelem, Banjarnegara". Skripsi.Yogyakarta: Program Studi Ilmu Komunikasi Universitas Islam Indonesia. 
Saputro, Johan. 2014. "Perencanaan Event Manajemen Festival Kesenian Yogyakarta sebagai Media Komunikasi Identitas Yogyakata". Skripsi. Yogyakarta: Program Studi Ilmu Komunikasi Universitas Islam Negeri Sunan Kalijaga Yogyakarta.

Sayoga, dkk. 2016. "Analisis Karakteristik Event Ohle Goes To Kampus Sebagai Strategi Komunikasi Pemasaran PT Pikiran Rakyat". E-Proceeding of Management.Bandung.

Septemuryantoro, Syaiful Ade dan Cindy Citya Dima. 2018. "Pembelajaran Wisata MICE (Meeting Incentive Conference Exhibition) untuk Menciptakan SDM MICE di Kalangan Mahasiswa Perhotelan Universitas Dian Nuswantoro". Prosiding SENDI_U. Semarang: 407-412.

Sauer, M. INSTITUTE OF HOSPITALITY MANAGEMENT IN PRAGUE

Siregar, Damara Saputra. 2014. "Pelaksanaan Manajemen Mice (Meeting Incentive Conference Exhibition) Di Hotel Pangeran Pekanbaru”. Jom FISIP, 1 (2): 1-12.

Sondang, Siagan. 2012. Fungsi-fungsi manajemen. Jakarta: Bumi Aksara.

Sugiyono. 2014. Metode Penelitian Pendidikan Pendekatan Kuantitatif, Kualitatif dan R\&D. Bandung: Alfabeta.

Sulistyowati, Nina dan Eka Harisma. 2016. Manajemen Event. Jakarta: PDD AKN Kabupaten Demak.

UNWTO (2016), Tourism Highlights, $2016 \quad$ edn., https://www.e unwto.org/doi/pdf/10.18111/9789284418145, accessed March 1, 2018.

Wijaya, Candra dan Muhammad Rifa'i (Ed). 2016. Dasar-Dasar Manajemen. Medan: Perdana Publishing. 